\title{
Waste and Effective Methods of Management
}

\author{
Idu Endurance $^{1^{*}} \quad$ Ufuoma Ugbune $^{1} \quad$ Bala Anegbe $^{2}$ \\ 1.Department of Chemistry Education, School of Sciences, Delta State College of Education, Mosogar, Nigeria \\ 2.Department of Basic and Industrial Chemistry, Western Delta University, P.M.B. 10, Oghara, Delta State
}

\begin{abstract}
This study will discuss the problem of environmental pollution and waste management. Everything that surrounds us is directly or indirectly related to the environment. Man and also other living beings as well as the nature (volcanic eruptions, earthquakes) have effects on environmental pollution. Environmental pollution is present from the very beginning of life, but today it is a serious problem that threatens the survival of mankind. During the preparation of scientific research, we noticed a problem: "What is the influence of the waste management on the environment?" Today, every person living on planet Earth is worried about environmental pollution because the consequences faced every day, through the air we breathe, the food and water we consume, through pollution and radiation we are exposed to. Also, the consequences of environmental problems are manifested through the lack of natural resources, extinction of plant and animal species, as well as the problems in the global ecosystems and biochemical processes. Based on the research problem we can hypothesize: Yes, waste management has a great impact on the environment.
\end{abstract}

Key words: Environment, Waste Management, Environmental Pollution, and Ecosystems.

DOI: $10.7176 / \mathrm{JEES} / 10-4-05$

Publication date: April $30^{\text {th }} 2020$

\subsection{Introduction}

The man, along with all other living beings from the beginning of its existence is closely linked with the entire inanimate and living nature that surrounds it. This interaction is the basis of the whole modern right of environmental protection. Through his own development, the man developed his interest in the way and manner that would harmonize with the nature that surrounds it, to ensure the conditions necessary for their survival. With each new discovery (ranging from tools for tillage and wheel all the way to modern computer technology) man makes bigger part of the eternal desire to reconcile nature and its needs. Contemporary urban, industrial, economic and technological development has provided great benefits to man, but the industrial air and water pollution, uncontrolled deforestation and their conversion into agricultural land, destruction of the ozone layer depletion and global warming of the planet followed by climatic changes, the accumulation of various wastes, including radioactive as well as the eradication of certain plant and animal species, are just some of thenegative consequences of human activities, which, however, seriously endangering his own survival. At present time, the protection of the environment is of great importance in the prevention and elimination of these contradictions. The right to protect the environment today should be seen as a uniquesupranational (international), national and local unit. Therefore, in order for the normative framework to succeed, actions must be taken at the universal, national, regional and local levels.

Today we can say that we live in a world ofwaste, because of population growth and production increasing amounts of waste that makes landfill are becoming more numerous and increasingly degrade the environment. Every day a huge amount of waste, equally as in the villages and in agricultural areas is produced. Every year, about 10 million tons of oil products reaches rivers and oceans and has more than 500 billion tons of industrial waste. Industrial facilities and transport throw into the atmosphere about a billion tons of aerosols and ash. At the landfill waste is collected for years. In the wild landfill reaches up to $70 \%$ of total waste. The biochemical processes of decomposition of waste adversely affect the environment. As for municipal waste that contaminates the soil and plants, air, groundwater and surface water on them in huge quantities reproduce rats, mice and insects, which contributes to the spread of infection. This new situation poses a threat to human health, for both present and future generations. This imposes the problem of protecting the environment through waste management. The composition of waste is very different and includes municipal solid waste, industrial, and agricultural, medical, electronic and other wastes of mixed composition.

A particular problem is hazardous waste (chemical,biological and nuclear) with a strong polluting effect and the many negative consequences for human health and the environment. In the early $90 \mathrm{~s}$ of the 20th century in developing countries, there are $100-330 \mathrm{~kg}$ of solid waste per capita in the European Union, the number was 414, and in North America $720 \mathrm{~kg}$. The global problem of all countries of the world is that there is an increase of waste, both in the amount of waste produced, as well as the amount of waste per person. The big problem is that this waste is not processed, instead, it is disposed of in landfills that are huge and located in the vicinity of cities and represent some dangerous pollutants to air, water and land. 


\subsection{Environmental pollution}

The result of deteriorating environmental situation in various countries and regions where environmental pollution is the most intense climate is warming, ozone layer is depleting, desertification. According to the definition adopted by the UN organization, pollution are exogenous chemical substances encountered on a suitable place, at the appropriate time and in inadequate quantities (Bjelajac, 2011). According to the analysis (taken in early 20th century), it is concluded that the most polluted spheres are atmosphere and hydrosphere. Even the state of cosmic space around our planet raises serious concerns. In order to define the concept of the environment, we must consider the basic ecological unit that has its own laws, which is characterized by complex factors of animate and inanimate nature. This unit is called an ecosystem. The man as a conscious being has a great influence on the environment. According to the methodology of the World Health Organization, there are 26 risk factors to health, some dating from the environment that are considered to cause many diseases in the population of children aged 0 to 19 years.

The impact of economic and other activities on the environment may be different in character: direct (immediate) and indirect synergy. From the perspective of environmental effects of pollutionare usually described in terms of which we have already pointed out: degradation, devastation, endangering the environment, in different time periods. It is possible to perceive the effects of pollution in air, water, soil, wildlife, human health,and so on. We can speak of long-termed and short-termed effects of pollution. It can be very important to understand the concept of the working environment, if it is connected with the concept of environmental protection in the context of discussions on environmental management. This can be done for many reasons. First, because of the connection of the working environment as part of the environment, there are connections and processes related to the operation and are of importance to the issue of the environment. There are several provisions in the law on safety and health at work and other regulations governing this area, which are directly relevant to the understanding of the relationship between the working environment and the environment. It is necessary to know not only the notion of working environment but also to bear in mind the definition of a number of other terms such as "hazardous materials", "danger", "dangerous phenomenon", "risk", "risk assessment", and so on. According to this law work environment defines the working environment in which the work is performed under specific operating conditionsin the workplace, working procedures andrelationships in the work process. Unfavorable changes in the environment caused by human activities, causing a change in the inflow of energy, radiation levels physicochemical and microbiological composition of environmental pollution can be defined. The harmful effect of pollution, their effect is manifested in the anatomical and morphological structure, metabolism, growth process, at all levels of cellular organization, from the molecular to the cellular level, through individual and population to biocenosis and ecosystems.

\subsection{Waste Management}

In the Middle Ages, food waste was dumped on the streets, so the rodents and insects transmitted many infectious diseases and dangerous epidemics. Today, because of inadequate treatment of waste could be a higher number of infectious diseases. The general interest of society in our country, governed by the Law on Waste Management is themanagement of waste. The objective of this law is to provide and ensure the conditions for waste management in a way that does not endanger human health and the environment. Law relating to waste management, is based on the following principles:

- The principle of optimal choice of options for the environment

- The principle of proximity and regional approach to waste management

- The principle of hierarchical waste management

- The principle of accountability

- The 'Polluter Pays' Principle.

Prevention of waste, reuse of waste and recycling, separation of recyclable materials from the waste and the use waste as an energy resource development processes and methods of wastedisposal, remediation of unregulated dumps, and developing awareness of waste management involves waste management. The concept of waste management refers to the activities of collecting, transporting, sorting, recycling, disposal, tracking and monitoring of waste. The biggest problem is the collection of waste for recycling, ie, waste sorting, because some parts of the process must be performed manually, which increases the cost of recycling. But there are problems with the categorization of garbage, so let's say PET bottles are not the same category of waste as PVC containers and cannot be recycled together. As the best solution for the protection of the environment from waste, would be not to use products or packaging thatis biodegradable and does not release toxins intothe atmosphere. As a consumer, you can choose the product you are buying. Products with excess packaging not only pollute the environment, packaging is included in the price you pay, and the placing of 30 grams in a package which can hold 60 grams of leads to visual misleading. Japan introduced legislation on recycling in 1997 and currently there are 44 categories of waste. Every resident of Japan has received a 27-page instruction on the procedure for sorting their waste. There are categories describe to you in detail, so if you have a lipstick that you spent, he throws himself into the category 
of combustion, but after you remove it from the packaging and plastics dumped into the category of "small plastic and metal. Japan is a country-specific, because with 127 million people, on average, 336 people live in an area of $1 \mathrm{~km}^{2}$. Logically Japan has to take care of as little use of land for the purpose of disposal.

In the world's major cities, there are $3.5 \mathrm{~kg}$ ofwaste per capita a day. With increased population and living standards, the waste also increases. According to the Basel Convention, the world annually produces about 400,000,000 tons of hazardous waste. Military waste and radiochemical industry, which uses various raw materials and products that have hazardous properties is especially present. The production of hazardous waste can occur in combat, destruction of chemical plants in NHB accidents (transport, storage, accidents, natural disasters, natural disasters) and so on. The harmful and dangerous contaminants working environment includes the physical (solid waste, dust, noise, vibrations), chemical (aerosols, gases, vapors, fumes, dust, waste), radiation (ionizing, UV, oils, infrared, radar, laser, ultrasound, x-ray) and biological (viruses, bacteria, mold, fungi, parasites, insects, rodents). Anthropogenic substances go into the environment in different ways. Wastewater is discharged into surface and underground waterways and basins. Solid waste is stored in special landfills, buried and deposited in abandoned mines. Agriculture uses fertilizers and pesticides (about 70,000 different harmful and hazardous substances, and the list is supplemented annually with new 900-1000 terms). Synthesized new compounds that are not found in the working environment and living organisms are able to decompose (PVC materials). It is estimated that close to 40 million plastic bottles and bags, a large number of lost and discarded fishing nets, nylon and others float on seas and oceans(Heleta, 2010).

\subsection{Disposal of solid waste in landfills}

Landfills are sites for solid waste disposal. There are several types of landfills depending on the manner in which the waste is thrown and protection measures aimed at preventing air pollution and pollution of groundwater. Atmosphere and hydrosphereare contaminated because of garbage disposal in open areas without protective measures. In order to prevent the contact of materials from solid waste with atmospheric air, sanitary landfills are built. Today, waste is disposed in the bowels of the Earth, which represents an alternative to landfill sites. In this way the air pollution is avoided and undesirable propagation of animals. This method of waste disposal has its disadvantages:

- If you make a wrong selection of underground landfill, it can contaminate groundwater.

- When waste is buried and located in the middle of the country, there is no oxygen and its decomposition. Biogas is formed, which consists of various hydrocarbons, mostly methane. Biogas is spread horizontally and can reach the basements of buildings and in contact with open flames it can ignite and explode.

- When waste is decomposed, its volume decreases, and this causes sagging area, so that in these places we cannot make buildings and other facilities.

\subsubsection{Strategies for building and controllinglandfill}

During the construction of landfills, there are three strategies:

- The waste is stored on land that has therequired properties and the ability of self-purification,in order to avoid the spreadof harmful substances into the surroundingenvironment. In this case, land is the onlybarrier to the polluting substance. Therefore, land should be chosen appropriately to meetspecific biological and chemical criteria (eg,clay, grain size distribution).

- Strategy of limiting i.e. limiting themaximum infiltration of pollutants fromthe landfill to land on one of the following:landfill covering material that is imperviousto water, in order to minimize the penetrationof atmospheric and surface water andpollution of soil in that way, by placinginsulating layer in the bottom of the landfillin order to prevent the penetration of waterand drainage system collects water that haspassed through the upper cover. This wateris purified again or returns to the landfill.

- The most modern conception considerslandfill as a kind of chemical reactor. Themodern approach consists of keeping theidea of limiting, but in a controlled manner,so as to form a controlled chemical reactor (Jovanovic L. , 1999).

\subsection{Industrial waste management}

A huge number of waste is created by technological and technical activities, but several types are re-used: metal, plastic, paper, glass. A number of issues from environmental protection consider the re-use of materials: to reduce the need for primary raw materials, reduce the pollution of water and soil. Industrial waste is divided into:

- Scrap

- waste wood

- $\quad$ waste plastics and other materials

- $\quad$ industrial waste.

Ecologically beneficial and comprehensive technologies that reduce the amount of the primary production is developing. Non-waste technology should provide: 
- Development and production of new products, taking into account the possibility of re-use;

- $\quad$ processing of production and everydaywaste into new products;

- The use of closed systems of industrialwater supply.

\subsection{Hazardous waste management}

As defined by the United States Agency forEnvironmental Protection hazardous waste is any waste that is flammable, corrosive, reactive or toxic. (Jovanovic L. , 1999)Hazardous waste today can be found at every turn. Studies have shown that the main source of this type of waste are:

- Chemical industry, with about $60 \%$ of the total industrial hazardous waste;

- metal industry, with about $20 \%$;

- military industry;

- pharmaceutical industry;

- clinical centers;

- $\quad$ household and

- small businesses

\subsubsection{Hazardous medical and veterinary waste}

The waste that is created in the health and veterinaryinstitutions, regardless of its composition and origin, is a medical-veterinary waste. This is a heterogeneous mixture of municipal garbage, infectious and laboratory waste, packaging, medicines and other pharmaceutical and chemical waste. Hazardous medical waste, which accounts for $14 \%$ of the total amount of medical waste consists of the following groups of waste:

- Infectious waste - from microbiology laboratoryequipment, supplies and accessories that came into contact with the bloodor infectious patients used in surgicalprocedures, waste with hemodialysis,gloves, trash infected experimental animals.

- $\quad$ Sharp Objects, needles, syringes, scalpelsand other objects that can cause a sting or cut.

- Gross, of black and gray parts of thehuman body (tissues, organs removedduring surgery), experimental animals, anatomical parts of animals.

- Pharmaceutical Industrial waste drugs and chemicals that have been returned to thedepartments from where they are taken orexpired.

- Chemical waste- discarded solid, liquid orgaseous chemicals that are used in medicalor experimental procedures, cleaning ordisinfecting.

- Radioactive of black and gray contaminatedmaterials, equipment, solutions, corpsesexperimental animals.

- Content of heavy metals from the wastepresent compounds of mercury, lead,arsenic, as well as thermometers, devices formeasuring blood pressure. Jovanovic (2000), The institutions of veterinary medicine waste is generated inthe following facilities:

- veterinary clinics,

- research laboratories of the institute,

- veterinary,

- veterinary clinics,

- numerous farms for breeding herds and flocks.

\subsection{Biodegradation}

A great potential for the processing of organiccomponents of municipal waste have biodegradation or composting. "Processing of one ton of organic waste may give $500 \mathrm{~m}^{3}$ of biogas, containing up to $70 \%$ of methane and carbondioxide due to the thermal capacity of up to $24,000 \mathrm{KJ} / \mathrm{m}^{3}$. It is vital for the presence of bacteria and other components of biota. Bacteria in quantity and diversity greatly exceed other groups of microorganisms. Bacteria perform the process of nitrogen fixation, which biological activity and soil fertility depend on. A significant portion of municipal solid waste consists of food scraps. They have a high density and humidity', (Jovanovic L. , 2000). In order to solve the problem of waste introduces the technique of biodegradation is introduced. In medium-sized cities and rural areas, biodegradation can be realized, especially on smaller farms and greenhouses. The final product of the degradation of the organic fertilizer, biogas (energy) and water that can be used in corporate and household advantage of biodegradation is ecological purity. Widely used method of biodegradation in economic practice in many countries for energy purposes and obtaining high-quality organic fertilizer, as well as reducing landfill surface processing of municipal solid waste in order to protect arable land and biodiversity.

\subsubsection{Technology biodegradation of organicwaste}

Micro-organisms are an inseparable component of ecological systems of the biosphere and their enormous activity released vast amounts of oxygen, which provides life on Earth. "Over the centuries, biodegradation of organic waste under the action of microbes took place. Today,men have learned to manage this process, synthesizing specific groups of microorganisms. In order to perform microbiological degradation of vegetable and animal waste, 
it is necessary to know the chemical structure of its parts. This structure varies depending on the composition of food products from which the waste is produced. The main 'suppliers' of organic food waste are processing industry, agricultural producers, as well as some institutions. "The remains of food and industrial waste of plant or animal origin are exploited in the following manner:

- solid waste from other municipal and industrial waste must be disposed of in the landfill;

- use organic waste as a fertilizer on agricultural land;

- bury the carcasses of domestic animals;

- discharge of industrial waste into the sewersystem of the city;

- disposal of waste in illegal dumps.

Municipal waste whose share in the total volumeof solid waste is quite high, should be, trough the method of processing, burning or pressing and its disposal in landfills of solid waste, which is not justified either environmentally or economically. There are always environmentally and economically effective methods of waste treatment. The solution of these problems is the introduction of biodegradation technology. Biodegradation is widely applied in the economic practices of European countries. Many West European farms meet their needs for energy and organic fertilizers by using this method. In Norway and Canada, a method of biodegradation of organic waste in individual households as well as in industry is widespread. In China is also widespread. Method of biodegradation is economically effective, it can be concluded. Its application can make a profit by selling fertilizer, which is a valuable product.

\subsection{Recycling}

Re-use of materials and its separation from waste is called recycling. This involves the collection, separation, processing and manufacture of new products from the used items or materials. Everything that can be reused and not thrown away is recycling. Without the introduction of recycling in daily school life it is impossible to imagine an integrated waste management system. There are recycling centers in the world who exploit material from old things to make new, but there are no such centers in our country. There are few centers such as Paper service where they can take the old paper in exchange for coins. There arenot any centers for recycling glass and hundreds of glass bottles are thrown every year. (Kolomeiceva \& Jovanovic, 2010) "Through recycling following strategic objectives are achieved:

- Saving raw resources (all materials are sourced from nature and have them in limited quantities).

- Energy saving (no energy loss in the primary processes, as well as in transport and processes which follow, and additional energy is obtained by burning materials that are not recycled).

- Environmental protection (waste materials degrade, and the recycling protects the environment).

- Creation of new jobs (processes in the recycling of materials include investment

knowledge and work, which creates the need for jobs)" (Rajovic, 2007).

\subsubsection{Materials for recycling}

"In terms of the Return of exploitation, materials can be:

- Recyclable (can be used to recapture theproduction process after recycling)

- Non-recyclable (cannot be returned to theproduction process and are used to obtainenergy-burning or in an environmentallysafe manner warehouse in landfills)

- Hazardous (materials that are harmful to humans and the environment)

- Harmless (materials that are not harmful to humans and the environment) By the way of returning the material in the process of re-use, recycling can be:

- Primary (recycling which after properpreparation materials used to obtain thesame product).

- Secondary (recycling, in which recyclablematerials are conventionally processedusing new technologies to the maximumpossible efficiency)" (Todic, 2008).

\subsubsection{Recycling of plastic waste}

Plastic waste is naturally very difficult to decompose.If you are re-using packaging waste contributes to reducing the amount of waste and environmental pollution, saving raw materials and energy. The big problem is caused by unlimited use of plastic products and dumping their remains. There are many ways to recycle plastics, although essentially it all boils down to the same operation. The technological process is composed of seven stages:

- Waste collection

- Identification and selection

- Milling

- Rinse

- $\quad$ Spinning

- Material drying

- Storage

The household plastic waste is put in the samebasket with other waste and creates another problem. In order 
to solve this problem containers depending on the type (glass, paper, plastic etc.) are introduced. In most EU countries, this method of collecting and sorting is already greatly in practice. "In the first decade of the 21 st century in the United States about 30 million tons of plastic waste is collected. Due to the problem of disposal of this waste, re-use becomes ever more important. Every year Americans use $86 \mathrm{~kg}$ of plastic of which $27 \mathrm{~kg}$ is packaging. Germany recycles about 800 tons of plastic, which represents $80 \%$ of the annual volume of plastic waste. UK recycles about 200 tons of plastic which is very small compared to the total amount. Since 2000 , the processing of plastic waste has increased, with one piece of plastic back to the landfill. It is a residue that cannot be processed. Great attention is paid to creating plastics that will be able to break down under the action of microorganisms. These are the so-called biodegradable plastics. Not all plastic products can be replaced with biodegradable plastic'. We don't process the plastic waste in an adequate way, although we have great potential. It is the processing of waste of known composition and origin. Capacities that perform processing are also very modest.

\subsubsection{Car-battery Recycling}

"Huge amounts of unselected waste are deposited at the landfills. Old batteries are disposed of during the year in landfills without any preparation area. This leads to significant soil contamination with lead, acids and other inorganic substances from the battery". In order to recycle old batteries, it is necessary to pre-allocate and recycle certain components and safely dispose of the waste that occurs as a residue after recycling. The technology of remaking old batteries is not particularly popular, although it has great economic justification and significant impact on the environment. Because of the difficulty of collecting old batteries from wild landfills, which are numerous, settling all kinds of waste materials, it is very difficult to make a selection, a very small number of companies are doing this. Statistics show that we cast away $1 / 4$ of the total number of batteries. One of the most important raw from re-cycled batteries is lead.

\subsubsection{Recycling of vehicles at the end of life}

"The car is a product of high complexity. Partsof the car are made of different materials but the most dominant is cast iron and steel. Approximately $80 \%$ of the weight of the car. can be recycledin the current recycling plants The process ofrecycling the car is complex because of the variety of materials that are part of the car. Glass, which is $3 \%$ of the weight of the car, is not processed in factories for the manufacture of glass, because of its complex chemical composition, but chipped used in construction as a concrete additive. Fluidsin cars (fuel, various types of oil and coolant) constitute $2 \%$ of the weight of the car. These fluids in the process of recycling the car significantly complicate the process itself, because of its chemical composition and its toxicity. Rubber, which makes $5 \%$ of the total weight of the car, goes further to industrial processing and has found applicationfor obtaining different products (flooring, protective fencing, addition to asphalt). "A major threat to the environment are batteries of old cars, then switch on the basis of living and different types of filters. The parts of the car should be treated separately and with great care. "Right now two technologies of recycling the cars are applied, which differ in the way of sorting the materials that make up the car. The first technology is based on optical separation, while other technology uses multiplemethods (mulching, gravitational and special methods of separation)".

\subsection{Waste Management Strategy}

"The collection, transport, storage and treatment of waste carry a number of risks to safety and health of employees in the waste industry". The system activities and activities which include the prevention of waste by reducing packaging materials, waste reduction, developing a habit of sorting waste in the population represents waste management. "Waste Management Strategy provides us with the following activities:

- The introduction of formal legal mechanisms, such as the acquisition of knowledge in the field of waste management.

- Acquisition and improvement of education and training of persons who manage waste

- Establishment of a national body responsible for the development of educational programs and training in the field of waste management.

There are ways to intensify the use of waste, to improve the quality of the processed raw materials and the number of participants in the recycling process which leads to greater environmental protection. Most countries accept the strategy of the European Union relating to:

- Research and development of new technologies for recycling

- Optimization of the system of collecting and sorting waste

- Reduction of external costs of re-use of waste

- Computerized systems of waste management

- $\quad$ exchange and sale of scrap material

\subsection{Conclusion}

The environment is changing through development of the industrial revolution and the beginning of the use of 
fossil fuels. people are thinking about this problem more and more, because it should not allow the industry to continue to develop and harm the environment. This way of thinking has led to the emergence of the concept of sustainable development. This concept implies the continued development of the industry in a way that has minimal environmental impact. To change the quality of the ecosystem brings harmful effects of pollutants present in the environment and thus to increase the potential negative impacts on human health in several ways. The survival of man and nature are brought into question trough this industrial mode of production that was supposed to make the man the master of nature. Pollution of the basic elements of the environment (air, water and land) reached alarming results. Landscapes and spaces that are beyond the reach of human activities still exist. People recognized and legally protected such natural goods. The life and working life of the man carried out in the urban areas and industrial zones, and only rare moments of rest in an oasis of pure nature. Some types of waste represent a major potential threat to the environment and human health. The company did not immediately and fully understand this danger. In many countries there are still no regulations on waste management. The amount of hazardous waste has increased dramatically in the last period due to different types of pesticides that are applied in agriculture and industrial waste containing toxic and cancerogenicsubstances. Worsening situation of global environmental - global warming, ozone layer depletion, acidification of the environment with the occurrence of acid rain and its consequences of global environmental problems: deforestation, soil degradation, loss of biodiversity and stocks of clean drinking water- is the result of deteriorating environmental situation in different countries and regions where environmental pollution is most intense. Reducing environmental pollution is an important goal of sustainable waste management. Recycling is one of the useful methods aimed at maximum utilization of energy and raw materials from waste. Most countries are opting for recycling becausein addition to eliminatingwaste they see economic solutions. Recycling keeps raw materials and energy. From discarded and useless products obtained raw materials that would be in a different situation should draw from natural resources. The growth of population and production of larger quantities of waste to landfill seems to become increasingly numerous and increasingly degrade the environment. Landfills cover large areas of arable land, grow in uncontrolled dumps with high risk of miraculous situation and require huge costs of eliminating them. In order to reduce the amount of generated waste it is necessary to improve waste management strategies starting from minimizing waste at source, via rebooting the use of secondary raw materials, recycling and disposal too.

\section{References}

Aye, L., \& Widjaya, E. (2006). Environmental and economic analysis of waste disposal options fr traditional markets in Indonesia. 26(10), 1180-1191.

Barros, A., Dekker, R., \& Scholten, V. (1998). A two-level network for recycling sand: A case study. European Journal of Operational Research, 110(2), 199-214.

Basu, R. (2009). Solid Waste management- A Model Study. Sies Journal of management(6), 20-24.

Berkun, M., Aras, E., \& Anilan, T. (2014). Solid waste management practices in Turkey. Journal of Material Cycles and Waste Management, 13(4), 305-313.

Bjelajac, Z. (2011). Ecological Policy of EU and its Criminal-Legal Draft. MP4.

Demirbas, A. (2011). Waste management, waste resource facilities and waste conversion processes. Energy Conversion and Management, 52(2), 1280-1287.

Dixon, N., \& Jones, D. (2005). Engineering properties of municipal solid waste. Geotextiles and Geomembranes, $23(3), 205-233$.

Giusti, L. (2009). A review of aste management practices and their impact on human health. Waste Management, $29(8), 2227-2239$.

Heleta, M. (2010). System management projecting of environmental. University Sinidunum.

Jovanovic, L. (1999). Ecomanagement in function of environmental protection in towns. Ecological movement of Novi Sad.

Jovanovic, L. (2000). Recycling as an important parts of sustainable development ISO14000.

Kolomeiceva, \& Jovanovic, L. (2010). Chemistry and Environmental Protection.

Ogwueleka, T. (2009). Municipal solid waste characteristics and management in Nigeria. Iranian Journal of Environmental Health Science and Engineering, 6(3), 173-180.

Rajeshwari, K., Latta, K., Pant, D., \& Kishore, V. (2001). A novel process using enhanced acidification and a UASB reactor for bioremediation of vegetable market waste. Waste Management \& Research the Journal of the International Solid Waste \& Public Cleansing Association Iswa, 19(4), 292-300.

Rajovic, G. (2007). Environmental awareness as a basis for sustainable development of rural areas of Montenegro. Ecological, scientific and professional society for environmental protection of serbia, 49.

Todic, D. (2008). Environmental management conditions of globalizaton. Megatrend University.

Wilson, D. (2007). Development drivers for waste management . Waste Management \& Research the Journal of the International Solid Waste \& Public Cleansing Association Iswa, 25(3), 198-207. 